\title{
PENGARUH CARA KEMATIAN DAN TAHAP PENURUNAN MUTU FILET IKAN NILA MERAH (Oreochromis niloticus)
}

\author{
Simson Masengi ${ }^{1}$, Winda Sary ${ }^{2}$, Yuliati Hotmauli Sipahutar ${ }^{3}$ \\ ${ }^{1}$ Pembina Mutu Hasil Kelautan dan Perikanan Ahli Madya \\ Ditjen Penguatan Daya Saing Produk Kelautan dan Perikanan \\ ${ }^{2}$ Taruna Politeknik Ahli Usaha Perikanan \\ ${ }^{3}$ Dosen Kepala Politeknik Ahli Usaha Perikanan \\ Politeknik Ahli Usaha Perikanan \\ Jalan AUP No. 1 Pasar Minggu, Jakarta Selatan 12520
}

Diterima: 11 September 2020/Disetujui: 31 Agustus 2021

Email: sarywinda98@yahoo.co.id

Cara sitasi: Masengi S, Sary W, Sipahutar YH. 2021. Pengaruh cara kematian dan tahap penurunan mutu filet ikan nila merah (Oreochromis niloticus). Jurnal Pengolahan Hasil Perikanan Indonesia. 24(2): 284-291

\begin{abstract}
Abstrak
Perubahan yang dialami ikan setelah mati berlangsung dalam tiga fase, yaitu fase pre rigor, rigor mortis, dan post rigor. Tujuan dari penelitian ini adalah mengetahui pengaruh cara kematian dan waktu preparasi terhadap penurunan kesegaran ikan (pre rigor, rigor mortis, dan post rigor) yang disimpan pada suhu chilling. Pengolahan data dilakukan dengan ANOVA menggunakan rancangan acak kelompok (RAK) yang terdiri dari cara mati (menggelepar, di es, dan ditusuk segera) serta waktu preparasi dimulai (prer igor, rigor dan post rigor) yang disimpan pada suhu chilling. Hasil penelitian pendahuluan berdasarkan parameter indeks rigor maupun nilai $\mathrm{pH}$ dari perlakuan ikan yang ditusuk mengalami penurunan mutu lebih lambat. Hasil penelitian utama laju kemunduran mutu filet ikan nila merah menunjukkan pengaruh nyata antara lama waktu penyimpanan pada setiap parameter uji filet ikan nila merah semua perlakuan. Berdasarkan parameter TVB dan nilai $\mathrm{pH}$ filet ikan nila merah mengalami laju penurunan mutu yang lebih lambat pada perlakuan dimatikan ditusuk dalam kondisi pre rigor.
\end{abstract}

Kata kunci: cara kematian, filet, ikan nila, tahap penurunan kesegaran

\section{Influence of Death Way and Stage of Reduction of The Quality Fillets of Nile Tilapia (Oreochromis niloticus)}

\begin{abstract}
The changes experienced by fish after death take place in three phases, namely the pre rigor, rigor mortis, and post rigor phases. Fillet products are more susceptible to contamination and loss of quality than whole fish. The purpose of this study was to determine the effect of the way of death to the stages of decreasing the freshness of fish (pre rigor, rigor mortis, and post rigor) and determine the effect of the way of death on the quality of fillet red tilapia fillets in the pre rigor, rigormortis, and postrigor phases stored at temperature chilling. Data processing was carried out using ANOVA where the research design used a Randomized Group Design (RAK) and further data analysis of Honest Significant Difference (BNJ). The results of the preliminary study based on the parameters of the rigor index and the $\mathrm{pH}$ value of the treatment of the fish being pricked developed a slower pace of decline in fish freshness. The main results of the decline in the quality of the red tilapia fillet showed a significant effect between the storage time on each parameter of the red tilapia fillet test for all treatments. Based on TVB parameters and the $\mathrm{pH}$ value of red tilapia fillets the rate of development of slower quality decreases when the treatment is stabbed in a pre rigor condition.
\end{abstract}

Keywords: fillet, freshness reduction stage, method of death, tilapia 


\section{PENDAHULUAN}

Salah satu sumber daya alam Indonesia yang mempunyai peluang pengembangan besar adalah ikan. Komposisi protein dan asam amino esensial pada ikan bermanfaat bagi tubuh sehingga ikan adalah bahan pangan yang memiliki nilai gizi tinggi (Adawyah 2007). Ikan nila merah merupakan bahan makanan yang akan mengalami transformasi mutu sesudah mati. Transformasi yang dialami berupa secara fisika, kimiawi maupun biologis. Secara umum, ikan akan mengalami tiga fase perubahan, yaitu fase prerigor, rigormortis, dan postrigor. Indikator perubahan kualitas ikan dapat di lihat dari fase perubahannya (Liviawaty dan Affrianto 2014).

Ekspor filet ikan nila Indonesia ke Amerika dan Eropa telah berlangsung selama hampir 30 tahun. Saat ini, pasar ekspor naik terus dengan nilai ekspor ke Amerika mencapai USD120 juta. Permintaan filet ikan tilapia di Amerika sangat besar, sehingga Amerika menjadi tujuan mayoritas ekspor filet ikan tilapia dan termasuk ikan nomor empat yang banyak dikonsumsi di Amerika (KKP 2019). Seperti komoditas perikanan lainnya filet ikan lebih mudah terkontaminasi dan turun mutunya dari pada ikan utuh. Fillet ikan memiliki karakteristik yang mudah busuk (perishable food). Komoditas ikan membutuhkan perhatian ekstra dalam penanganan dan pengolahannya dibandingkan dengan komoditas olahan yang lain (Rostini 2007).

Tingkat ikan segar menjadi salah satu faktor yang menentukan nilai jual ikan dan hasil perikanan. Segar identik dengan mutu produk. Dalam industri perikanan, baik buruknya penanganan ikan sejak mulai tangkap sangat menentukan mutu ikan atau nilai kesegaran. Proses perubahan fisika, kimiawi, dan organoleptik setelah ikan mati berjalan dengan cepat. Cara ikan mati mempunyai pengaruh yang besar terhadap berawal dan berakhirnya rigor mortis sehingga akan memengaruhi mutu dan daya awet ikan (Junianto 2003).Penelitian ini dilakukan untuk memahami pengaruh cara kematian pada tahap penurunan kesegaran ikan (prerigor, rigormortis, dan postrigor) dan mengetahui pengaruh cara mati terhadap mutu filet ikan nila merah yang di simpan pada suhu chilling.

\section{BAHAN DAN METODE BAHAN DAN Alat}

Bahan yang digunakan pada penelitian ini adalah ikan nila merah dengan berat ratarata 150-200 g. Larutan yang digunakan untuk uji TVB yaitu TCA $7 \%, \mathrm{H}_{3} \mathrm{BO}_{3} 2 \%, \mathrm{~K}_{2} \mathrm{CO}_{3}$ (1:1), vaselin, indikator conway, kertas saring, es. Alat yang digunakan adalah score sheet organoleptik

\section{METODE PENELITIAN Desain Penelitian}

Penelitian dilakukan dengan eksperimen rancangan acak kelompok dengan perlakuan tiga cara kematian ikan yaitu menggelepar, diberi es dan ditusuk dengan variabel pre rigor, rigor mortis, dan post rigor dengan tiga kali ulangan. Penelitian pendahuluan diawali dengan mengamati fase penurunan kesegaran ikan (pre rigor, rigor mortis, dan post rigor) terhadap tiga cara perlakuan kematian ikan nila merah yang berbeda dengan parameter indeks rigor dan nilai $\mathrm{pH}$. Pengamatan terhadap indeks rigor dan derajat keasaman $(\mathrm{pH})$ mulai dari ikan mati hingga didapat titik waktu dimulainya tahapan pre rigor, rigormortis, dan post rigor. Titik-titik ini selanjutnya digunakan untuk pengambilan sampel filet untuk uji objektif dan subjektif pada penelitian utama. Penelitian utama bertujuan mengetahui tingkat kesegaran filet ikan nila merah dengan perlakuan cara kematian yang difilet pada tahap prerigor, rigor mortis, dan postrigor dan disimpan pada suhu chilling dengan mengamati perubahan mutunya pada hari ke $0,2,4$, dan 6 hari. Parameter uji yaitu uji organoleptik, $\mathrm{pH}$ dan TVB.

\section{Analisis data}

Analisis data dmenggunakan Anova dan bila berbeda nyata dilanjutkan dengan uji lanjut Dunnet. Analisis data organoletik dengan non parametrik Kruskal Wallis. 


\section{HASIL DAN PEMBAHASAN Penelitian Pendahuluan Indeks rigor}

Pengukuran indeks rigor bertujuan untuk mengetahui dimulainya ikan nila merah memasuki tahap penurunan kesegaran ikan yaitu fase prerigor, rigor mortis, dan postrigor. Tahap-tahap tersebut akan digunakan untuk pengambilan sampel pada penelitian utama. Pengukuran dilakukan setiap dua menit sekali selama 14 jam. Laju kemunduran mutu berdasarkan indeks rigor disajikan pada Figure 1.

Hasil analisis parameter indeks rigor dari tiga perlakuan cara kematian ikan nila merah menunjukkan laju perkembangan fase penurunan kesegaran ikan yang berbedabeda. Penelitian ini menemukan bahwa laju perkembangan fase penurunan ikan segar pada ikan nila merah dengan perlakuan dibiarkan menggelepar sampai mati laju perkembangan fase penurunan kesegaran ikan lebih cepat dibandingkan dengan ikan yang dimatikan menggunakan es dan ditusuk. Dari ketiga perlakuan cara kematian tersebut, perlakuan ikan yang ditusuk mengalami laju perkembangan fase penurunan kesegaran ikan berlangsung lebih lambat. Ikan nila merah pada perlakuan dibiarkan menggelepar sampai mati, mencapai rigor mortis lebih cepat karena menyebabkan ikan terluka, sisik terlepas dari badan ikan dan energi hilang (Prabowo 2014). Penghancuran otak ikan yang telah ditangkap secara langsung membutuhkan waktu yang lebih lama untuk mencapai fase rigor mortis, karena tidak ada aktivitas otot selama proses (Robb 2002). Di awal kematian ikan yang dibiarkan mati menggelepar dibandingkan dengan ikan yang langsung mengalami kematian memiliki kandungan glikogen berbeda (Zailanie 2015).

\section{Nilai pH}

Tingkat kesegaran dari ikan dapat ditunjukkan dengan nilai $\mathrm{pH}$. Ikan yang tidak segar memiliki nilai $\mathrm{pH}$ basa dibandingkan ikan yang masih segar karena timbulnya senyawa yang bersifat basa, seperti $\mathrm{NH}_{3}$, $\mathrm{C}_{3} \mathrm{H}_{9} \mathrm{~N}$ dan senyawa basa volatil lain (Poli et al. 2005). Pada penelitian pendahuluan tujuan pengujian nilai $\mathrm{pH}$ bertujuan untuk mengetahui dimulainya ikan nila merah memasuki fase prerigor, rigor mortis, dan postrigor. Kemudian tahap tersebut akan digunakan untuk pengambilan sampel pada penelitian utama. Perubahan nilai $\mathrm{pH}$ ikan nila merah dengan berbagai cara kematian disajikan pada Figure 2.

Hasil analisis parameter nilai $\mathrm{pH}$ dari tiga perlakuan cara kematian ikan nila merah, laju perkembangan fase penurunan kesegaran ikan menunjukan perbedaan laju perkembangan yang berbeda-beda. Dalam penelitian ini ditemukan bahwa laju perkembangan fase penurunan ikan segar pada nila merah dengan cara dibiarkan menggelepar sampai binasa laju perkembangan fase penurunan kesegaran ikan lebih cepat dibandingkan dengan ikan yang dimatikan menggunakan es dan ditusuk. Dari ketiga perlakuan cara kematian tersebut,

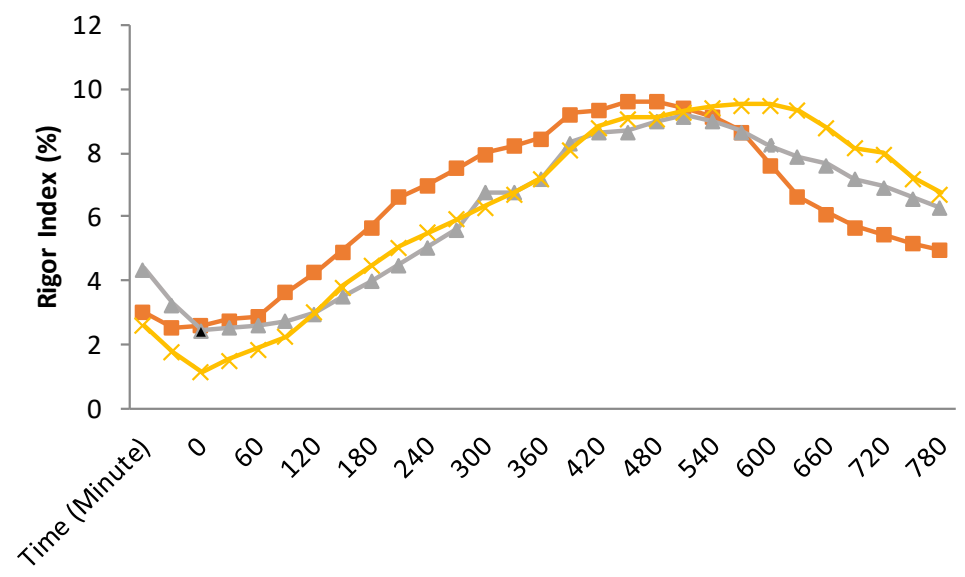

Figure 1 Rigor index of nile tilapia with three different death treatment; $\longrightarrow$ - by flounder; $\longrightarrow$ by ice; $\longrightarrow$ by stab. 


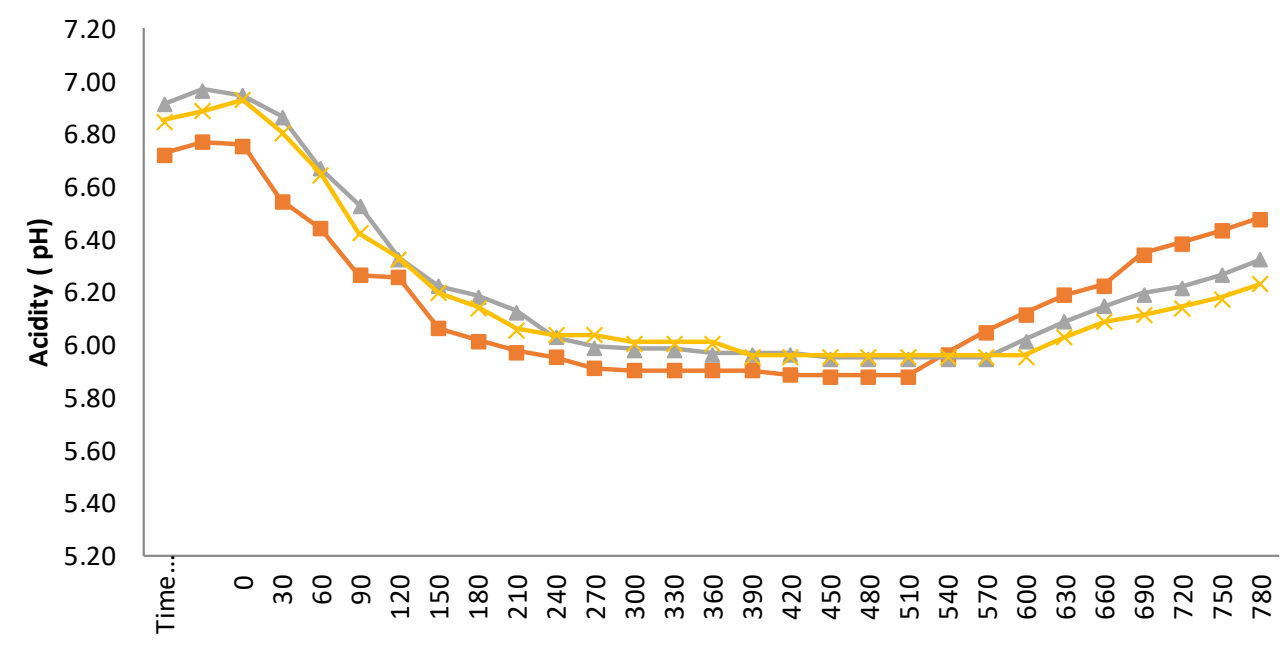

Figure $2 \mathrm{pH}$ of nile tilapia with three different death treatment; $\longrightarrow$ by flounder; $-\longrightarrow$ by ice;

by stab.

perlakuan ikan yang ditusuk mengalami perkembangan fase penurunan kesegaran ikan berlangsung lebih lambat. Energi yang terdapat dalam tubuh ikan akan terpecah habis pada cara mati ikan yang membutuhkan perjuangan yang hebat (Reo 2010). Perjuangan hebat serta metode penanganan kasar yang menyebabkan ikan rusak pada kematian ikan, akan menurunkan umur simpan dan menurunkan mutu ikan (Junianto 2003).

\section{Penelitian Utama Uji organoleptik}

Uji sensori (organoleptik) merupakan pengujian yang cepat dan lebih murah dibandingkan uji laboratorium yang membutuhkan banyak waktu dan biaya. Cara ini dapat membedakan secara kasar ikan yang busuk dan ikan yang segar dengan melihat tanda-tanda pada tubuh ikan (Liviawaty 2001).

\section{Kenampakan}

Daging merupakan parameter utama dalam penentuan kualitas kesegaran ikan. Perbedaan daging ikan segar memiliki sayatan yang masih cemerlang dibandingkan ikan busuk yang warna dagingnya kusam (Liviawaty 2001). Parameter kenampakan daging/filet ikan nila merah dengan berbagai cara kematian disajikan pada Figure 3.
Kenampakan filet dengan lama
penyimpanan berbeda menunjukkan perbedaan nyata pada kematian dengan cara menggelepar, menggunakan es, dan ditusuk pada fase prerigor, rigor mortis, dan postrigor. Penilaian pada periode penyimpanan hari ke-4 kenampakan filet tidak dapat diterima. Pada periode penyimpanan hari ke-2 kenampakan filet masih dapat diterima oleh panelis. Filet ikan dapat diperpanjang masa simpannya hingga mencapai 1 sampai 4 minggu pada perlakuan penyimpanan suhu rendah, dilihat juga dari jenis ikan dan cara penanganannya (Stein et al. 2005). Perlakuan dimatikan setelah 12 jam tanpa media air dibandingkan dengan perlakuan dimatikan segera mengalami kemunduran mutu yang lebih cepat karena kandungan glikogen yang lebih sedikit (Nurilmala 2009).

\section{Bau}

Parameter bau pada filet dengan cara kematian menggelepar prerigor, rigor mortis, dan postrigor dari analisis kruskal wallis uji organoleptik menghasilkan periode waktu penyimpanan berpengaruh sangat nyata terhadap bau $(p<0,05)$. Filet dengan cara kematian menggunakan es prerigor, rigor mortis, dan postrigor periode waktu penyimpanan berpengaruh sangat nyata terhadap bau $(p<0,05)$. Periode waktu 


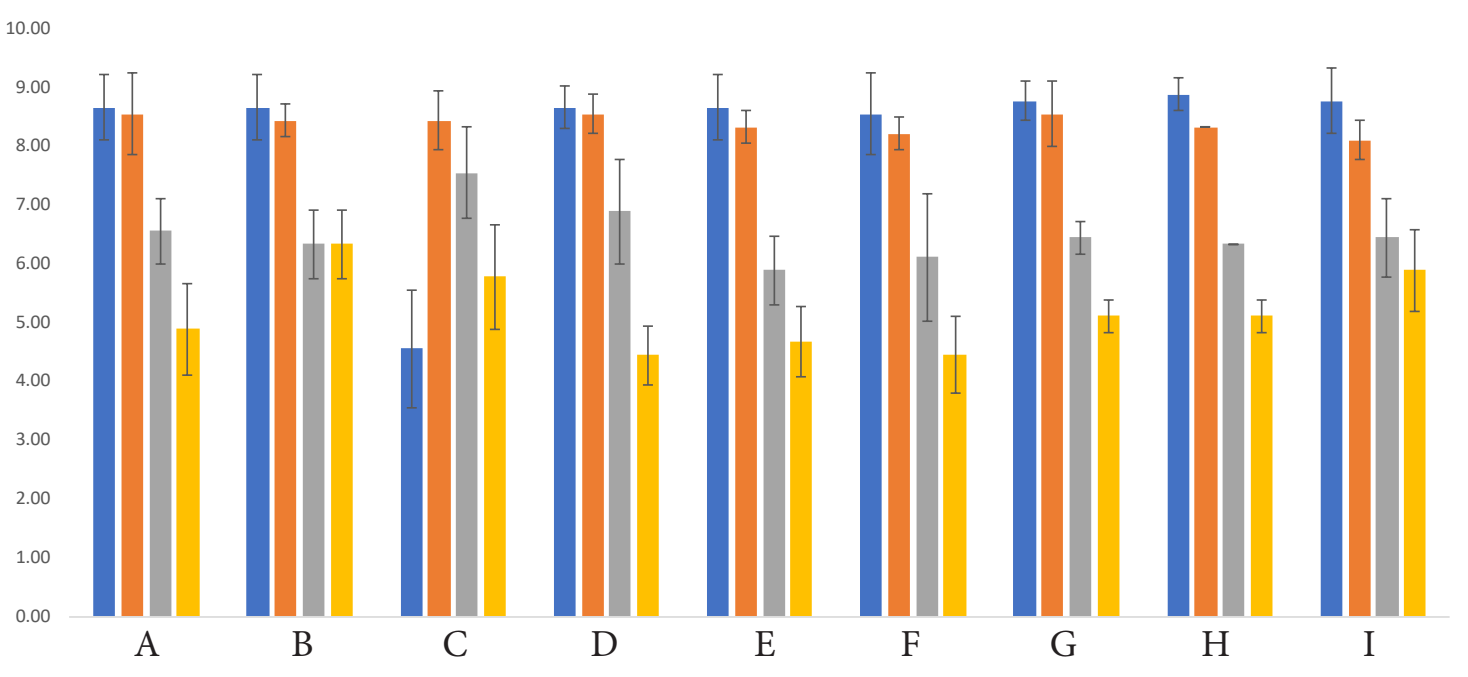

Figure 3 Appearance of nile tilapia with three different death treatment; $\square 0$ day; $\square 2$ days; 4 days; 6 days; (A) flounder prerigor; (B) flounder rigor mortis; (C) flounder postrigor; (D)ice prerigor; (E) ice rigor mortis; $(F)$ ice postrigor; $(\mathrm{G})$ stab prerigor; $(\mathrm{H})$ stab rigor mortis; (I) stab postrigor.

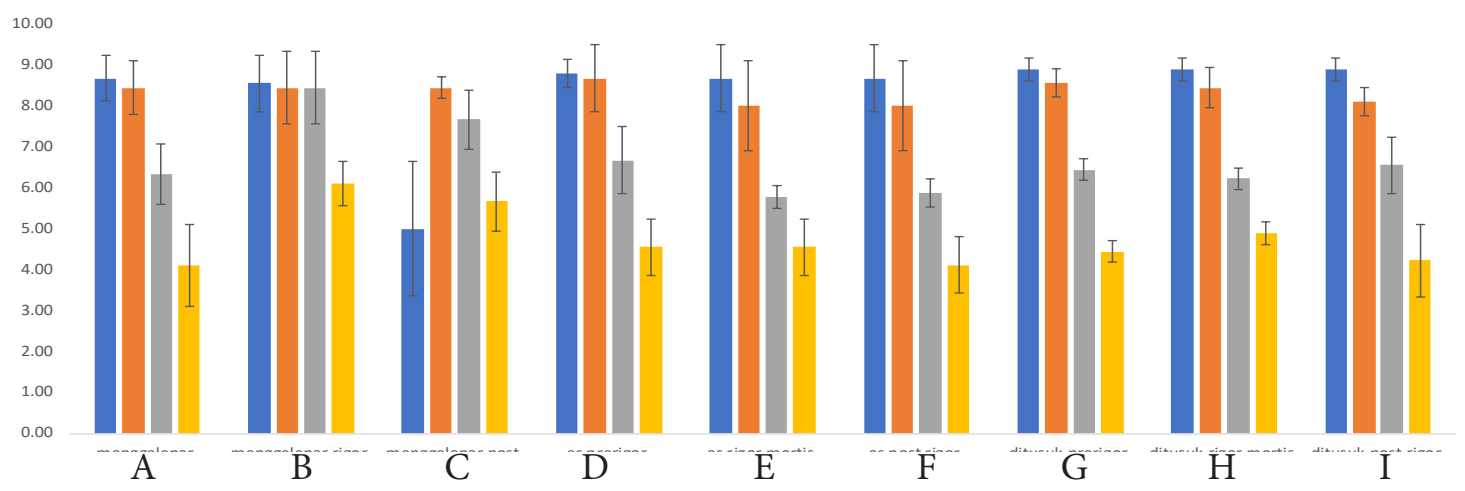

Figure 4 Aroma of nile tilapia with three different death treatment; $\square 0$ day; $\square 2$ days; 4 days; 6 days; (A) flounder prerigor; (B) flounder rigor mortis; (C) flounder postrigor; (D)ice prerigor; (E) ice rigor mortis; (F) ice postrigor; $(\mathrm{G})$ stab prerigor; $(\mathrm{H})$ stab rigor mortis; (I) stab postrigor.

penyimpanan memiliki pengaruh sangat nyata terhadap bau $(p<0,05)$ pada filet dengan cara kematian ditusuk prerigor, rigormortis, dan postrigor.

Pada periode penyimpanan hari ke4, bau filet tidak dapat diterima sedangkan penyimpanan hari ke-2 bau filet masih dapat diterima oleh panelis. Hal ini disebabkan filet ikan mengalami proses oksidasi. Proses oksidasi lemak pada daging ikan dapat menyebabkan aroma tengik (Nurilmala 2009). Perubahan bau selama penyimpanan dari berbagai cara mati pada filet ikan nila merah disajikan pada Figure 4.

\section{Tekstur}

Filet ikan dengan cara kematian menggelepar, menggunakan es, serta ditusuk pada fase prerigor, rigor mortis, dan postrigor dengan lama penyimpanan sangat berbeda nyata terhadap tekstur filet. Pada penyimpanan hari ke-4 nilai tekstur filet tidak dapat diterima panelis. Penyimpanan hari ke-2 tekstur filet masih dapat diterima oleh panelis. Filet ikan akan mengalami penyusutan pada daging disebabkan oleh tidak adanya rangka yang mampu menyangga bagian daging filet dan kontraksi otot yang terjadi pada daging menyebabkan tekstur filet berubah pada saat penyimpanan (Erikson dan Misimi 2008). 


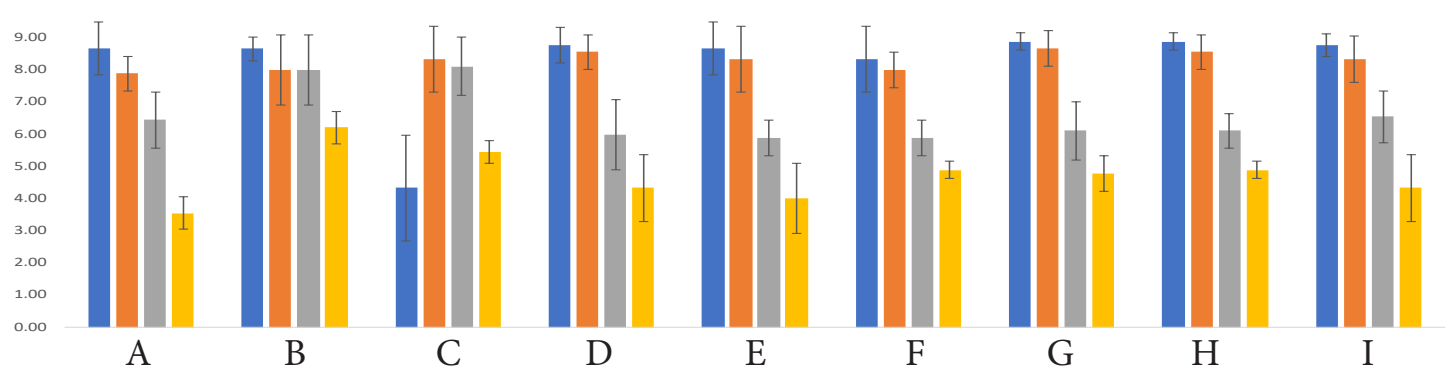

Figure 5 Texture of nile tilapia with three different death treatment; 0 day; 2 days; 4 days; 6 days; (A) flounder prerigor; (B) flounder rigor mortis; (C) flounder postrigor; (D)ice prerigor; (E) ice rigor mortis; (F) ice postrigor; $(\mathrm{G})$ stab prerigor; $(\mathrm{H})$ stab rigor mortis; (I) stab postrigor.

Dua hal yang menyebabkan tingkat kesegaran ikan menurun yaitu proses transformasi pada fillet ikan yang disebabkan kegiatan enzim dan mikroorganisme (Weber et al. 2008).

Setelah ikan mati akan mengalami autolisis, kimiawi, dan bakterial. Sehingga ikan mengalami perubahan biokimia dan mulai terjadi deteriorasi (Suwetja 2011). Kesimpulan hasil analisis pada filet ikan yang dimatikan dengan cara menggelepar, menggunakan es, dan ditusuk pada fase prerigor, rigor mortis, dan postrigor bahwa filet memberikan pengaruh berbeda nyata pada parameter kenampakan, bau, dan tekstur, yaitu interaksi terjadi pada nilai $p<0,05$ selama proses penyimpanan dari hari ke-0 hingga hari ke-6. Ikan dalam keadaan stres akan menghasilkan daging kaku dan dapat menyebabkan filet kurang bagus serta menyusut ketika dipisahkan (Peterson 2007). Perubahan tekstur filet nila merah dengan berbagai cara kematian dan fase mortis disajikan pada Figure 5.

\section{Uji total volatile base (TVB)}

Salah satu pengujian yang berfungsi menentukan ikan segar yang didasarkan pada akumulasi senyawa-senyawa basa seperti $\mathrm{NH}_{3}, \mathrm{C}_{3} \mathrm{H}_{9} \mathrm{~N}$ dan senyawa basa volatil yang menguap adalah uji TVB. Senyawa tersebut akan terkumpul pada daging setelah ikan mati (Nurilmala 2009). Hasil analisis TVB filet ikan nila merah dengan berbagai cara kematian dan fase mortis disajikan pada Table 1.

Hasil penelitian menunjukkan bahwa nilai TVB filet ikan pada awal penyimpanan masih dalam keadaan segar. Pada suhu chilling penyimpanan filet ikan nila merah mampu memperlambat peningkatan nilai TVB. Zulaikha et al. (2007) menyatakan bahwa penyimpanan suhu chilling menghasilkan nilai TVB lebih rendah dibandingkan penyimpanan suhu ruang. Peningkatan nilai TVB dapat berjalan lambat dengan menggunakan suhu rendah dalam penyimpanan, pertumbuhan bakteri, dan kegiatan enzimatis.

Filet pada ikan yang dimatikan dengan cara menggelepar, menggunakan es, dan ditusuk yang pada fase prerigor, rigor mortis, dan postrigor selama penyimpanan dari hari ke-0 hingga hari ke-6, menunjukkan pengaruh yang berbeda nyata terhadap kadar TVB pada nilai $p<0,05$. Nilai rata-rata TVB filet ikan nila merah dengan perlakuan menggelepar dan menggunakan es lebih cepat mengalami kenaikan nilai TVB dibandingkan filet ikan nila merah dengan perlakuan ditusuk. Perlakuan kematian ditusuk yang difilet pada kondisi prerigor mengalami peningkatan nilai TVB lebih lambat daripada perlakuan lainnya. Ikan nila merah dengan perlakuan menggelepar memiliki perbedaan nilai TVB dibandingkan dengan menggunakan es karena kandungan energi yang sedikit disebabkan kontraksi sesaat sebelum kematian. $\mathrm{pH}$ ikan cepat menurun pada ikan yang kehilangan energi lebih banyak sebelum kematian sehingga terjadi aktivitas enzim yang dapat menguraikan protein. Nilai TVB meningkat apabila terjadi penguraian yang meningkatkan basa-basa volatil (Nurilmala 2009).

\section{Uji pH}

Indikator yang biasa digunakan untuk menentukan tingkat ikan segar adalah 
Table $1 \mathrm{pH}$ and TVB of nile tilapia with three different death treatment

\begin{tabular}{|c|c|c|c|c|c|c|c|}
\hline \multirow[b]{2}{*}{ Phase } & \multirow[b]{2}{*}{ Days } & \multicolumn{2}{|c|}{ Flounder } & \multicolumn{2}{|c|}{ Ice } & \multicolumn{2}{|c|}{ Stab } \\
\hline & & $\mathrm{pH}$ & $\begin{array}{c}\text { TVB } \\
(\mathrm{mgN} / 100 \mathrm{~g})\end{array}$ & $\mathrm{pH}$ & $\begin{array}{c}\text { TVB } \\
(\mathrm{mgN} / 100 \mathrm{~g})\end{array}$ & $\mathrm{pH}$ & $\begin{array}{c}\text { TVB } \\
(\mathrm{mgN} / 100 \mathrm{~g})\end{array}$ \\
\hline \multirow{4}{*}{ Prerigor } & 0 & $6.97 \pm 0.06$ & $14.22 \pm 0.25$ & $7.00 \pm 0.01$ & $10.30 \pm 0.28$ & $7.51 \pm 1.42$ & $7.04 \pm 0.08$ \\
\hline & 2 & $6.76 \pm 0.00$ & $15.63 \pm 0.02$ & $6.81 \pm 0.06$ & $22.12 \pm 0.51$ & $10.89 \pm 0.02$ & $6.87 \pm 0.00$ \\
\hline & 4 & $6.68 \pm 0.03$ & $20.61 \pm 0.15$ & $6.68 \pm 0.02$ & $23.78 \pm 0.30$ & $13.92 \pm 2.79$ & $6.68 \pm 0.01$ \\
\hline & 6 & $6.83 \pm 0.04$ & $28.39 \pm 1.74$ & $6.74 \pm 0.02$ & $22.66 \pm 3.16$ & $23.32 \pm 0.88$ & $6.73 \pm 0.01$ \\
\hline \multirow{4}{*}{ Rigor mortis } & 0 & $6.36 \pm 0.13$ & $16.10 \pm 3.86$ & $6.44 \pm 0.10$ & $13.11 \pm 0.29$ & $11.16 \pm 3.37$ & $6.46 \pm 0.11$ \\
\hline & 2 & $6.26 \pm 0.11$ & $17.00 \pm 0.80$ & $6.29 \pm 0.06$ & $19.33 \pm 0.21$ & $13.83 \pm 1.25$ & $6.33 \pm 0.02$ \\
\hline & 4 & $6.15 \pm 0.06$ & $22.67 \pm 4.90$ & $6.23 \pm 0.02$ & $26.31 \pm 0.34$ & $18.36 \pm 3.32$ & $6.25 \pm 0.03$ \\
\hline & 6 & $6.30 \pm 0.04$ & $26.21 \pm 1.27$ & $6.30 \pm 0.06$ & $25.02 \pm 0.91$ & $27.08 \pm 0.40$ & $6.35 \pm 0.00$ \\
\hline \multirow{4}{*}{ Postrigor } & 0 & $6.84 \pm 0.04$ & $16.69 \pm 3.34$ & $6.83 \pm 0.04$ & $15.30 \pm 0.25$ & $16.45 \pm 5.87$ & $6.89 \pm 0.00$ \\
\hline & 2 & $6.72 \pm 0.06$ & $18.40 \pm 0.48$ & $6.66 \pm 0.02$ & $22.81 \pm 0.44$ & $21.79 \pm 0.02$ & $6.76 \pm 0.00$ \\
\hline & 4 & $6.65 \pm 0.09$ & $25.31 \pm 4.70$ & $6.67 \pm 0.13$ & $27.52 \pm 2.41$ & $22.54 \pm 0.73$ & $6.65 \pm 0.06$ \\
\hline & 6 & $6.94 \pm 0.02$ & $32.40 \pm 0.02$ & $6.91 \pm 0.03$ & $28.86 \pm 1.15$ & $29.11 \pm 0.01$ & $6.58 \pm 0.22$ \\
\hline
\end{tabular}

nilai pH. Pada pembusukan ikan, aktivitas autolisis dan bakteri memengaruhi nilai $\mathrm{pH}$ daging yang sangat besar (Munandar 2009). Perubahan nilai $\mathrm{pH}$ filet ikan nila merah dengan berbagai cara kematian waktu mortem disajikan pada Table 1 .

Hasil analisis filet ikan yang dimatikan dengan cara menggelepar, menggunakan es, dan ditusuk pada fase prerigor, rigor mortis, dan postrigor dapat disimpulkan terdapat perbedaan kandungan nilai $\mathrm{pH}$ yang berbeda nyata pada $p<0,05$ pada penyimpanan dari hari ke-0 hingga hari ke-6. Kecepatan rata-rata $\mathrm{pH}$ filet nila merah perlakuan menggelepar dan menggunakan es lebih cepat mengalami kenaikan $\mathrm{pH}$ dibandingkan filet ikan nila merah dengan perlakuan ditusuk. Perlakuan kematian ditusuk pada kondisi prerigor mengalami peningkatan nilai $\mathrm{pH}$ yang lebih kecil daripada perlakuan lainnya. Transformasi $\mathrm{pH}$ lebih lambat pada ikan yang dimatikan segera dibandingkan ikan perlakuan dimatikan sesudah 12 jam tanpa air selama disimpan di suhu chilling (Nurilmala 2009). Apabila suhu yang digunakan rendah, maka kecepatan peningkatan nilai $\mathrm{pH}$ akan semakin lambat (Zulaikha et al. 2007). Kondisi ikan sesaat sebelum mati memengaruhi kecepatan perubahan nilai $\mathrm{pH}$. Terjadi peningkatan aktivitas otot pada keadaan ikan yang stres sebelum kematian dibandingkan kondisi ikan yang tidak stres sehingga membuat cadangan glikogen pada daging ikan berkurang (Stein et al. 2005).

Hasil analisis juga menunjukkan semua perlakuan ikan pada fase prerigor dengan penyimpanan dari hari ke-0 hingga hari ke-6 mengalami penurunan $\mathrm{pH}$. Penurunan nilai $\mathrm{pH}$ disebabkan semakin banyaknya asam laktat yang terbentuk dan penurunan ATP. Saat fase rigor mortis nilai $\mathrm{pH}$ akan semakin asam yang disebabkan katabolime ATP dan glikogen. Banyaknya glikogen yang ada di dalam daging ikan sebelum ikan mengalami kematian dan volume bufer dari daging ikan memengaruhi nilai pH (Jiang 2000). Akumulasi basa-basa volatil menyebabkan $\mathrm{pH}$ turun dan mengalami kenaikan pada fase postrigor dan busuk (Nurhayati 2011).

\section{KESIMPULAN}

Berdasarkan parameter indeks rigor maupun nilai $\mathrm{pH}$ bahwa laju perkembangan fase penurunan kesegaran ikan pada ikan nila merah dengan perlakuan dibiarkan menggelepar sampai mati perkembangan laju fase penurunan kesegaran ikan lebih cepat dibandingkan dengan ikan yang dimatikan 
menggunakan es dan ditusuk. Dari ketiga perlakuan cara kematian tersebut, perlakuan ikan yang ditusuk mengalami perkembangan laju fase penurunan kesegaran ikan yang berlangsung lebih lambat. Berdasarkan parameter TVB dan nilai $\mathrm{pH}$ filet ikan nila merah mengalami laju perkembangan penurunan mutu yang lebih lambat pada perlakuan dimatikan dengan ditusuk dalam kondisi pre rigor.

\section{DAFTAR PUSTAKA}

Adawyah R. 2007. Pengolahan dan Pengaweatan Ikan. Jakarta: Bumi Aksara.

Jiang ST. 2000. Enzymes and their Effect on Seafood Texture. New York: Marcel DEKKER, Inc.

Junianto. 2003. Teknik Penanganan ikan. Yogyakarta: Penebar Swadaya.

[KKP]. Kementerian Kelautan dan Perikanan. 2019. Mengenal Tilapia, Si Lezat dan Kaya Manfaat. [Internet]. Jakarta. Tersedia pada: https://kkp.go.id/bkipm/ artikel/9755-mengenal-tilapia-si-lezatdan-kaya-manfaat.

Liviawaty E. 2001. Organoleptik Ikan. Laboratorium Teknologi Pengolahan Hasil Perikanan. Bandung: Fakultas Pertanian. Universitas Padjajaran.

Liviawaty E, Affrianto E. 2014. Penentuan waktu rigor mortis ikan nila merah (Oreochromis Niloticus) berdasarkan pola perubahan derajat keasaman. Jurnal Akuatika. 5(1): 40-44.

Munandar A. 2009. Kemunduran mutu ikan nila (Oreochromis niloticus) pada penyimpanan suhu rendah dengan perlakuan cara kematian dan penyiangan. [Skripsi]. Bogor (ID): Institut Pertanian Bogor.

Nurhayati T, Salamah E, Tampubolon K, Apriland A. 2011. Peranan inhibitor katepsin dari ikan patin (Pangasius hypophthalmus) dalam menghambat kemunduran mutu ikan bandeng (Chanos chanos Forskal). Jurnal Pengolahan Hasil Perikanan Indonesia. 14(1): 49-55.

Nurilmala M, Nurjanah, Utama RH. 2009. Kemunduran mutu ikan lele dumbo (Clarias gariepinus) pada penyimpanan suhu chilling dengan perlakuan cara mati. FJurnal Pengolahan Hasil Perikanan Indonesia. 12(1): 1-16.

Peterson J. 2007. Cooking : Fish. London (UK): Ten Speed Press.

Poli BM, Parisi G, Scappini F, Zampacavallo G. 2005. Fish welfare and quality as affected by pre-slaughter and slaughter management. Aquaculture International 13: $29-49$.

Reo A. 2010. Pengaruh beberapa cara kematian ikan terhadap mutu ikan kakap (Lutjanus sp.). Jurnal Perikanan dan Kelautan Tropis. VI-3.

Robb D. 2002. The killing of quality: the impact of slaughter procedures on fish flesh. Di dalam: Alasavar C, Taylor T, editor. Seafood-Quality, Technology and Nutraceutical Applications. Germany: Springer-Verlag Berlin Heidelberg.

Rostini I. 2007. Peranan bakteri asam laktat (Lactobacillus plantarum) terhadap masa simpan filet nila merah pada suhu rendah. Universitas Padjadjaran Fakultas Perikanan dan Ilmu Kelautan.

Suwetja IK. 2011. Biokimia Hasil Perikanan. Jakarta: Media Prima Aksara.

Weber J, Bochi VC, Ribeiro CP, Victo AM, Emanuelli T. 2008. Effect of different cooking methods on the oxidation, proximate and fatty acid composition of silver catfish (Rhamdia quelen) fillets. Food Chemistry 106(2008):140-146.

Zailanie K. 2015. Fish Handling. Malang: Universitas Brawijaya Press.

Zulaikha F, Nurjanah, Nurhayati T. 2007. Karakteristik mutu ikan bandeng (Chanos chanos) di tambak Sambiroto Kabupaten Pati Jawa Tengah. [Skripsi]. Bogor (ID): Institut Pertanian Bogor. 